\title{
Inna codzienność. Funkcjonowanie Wenecji jako miasta bez samochodów
}

\author{
Hubert Trammer \\ Katedra Architektury Urbanistyki i Planowania Przestrzennego, \\ Wydział Budownictwa i Architektury, Politechnika Lubelska, \\ e-mail:huberttrammer@wp.pl,h.trammer@pollub.pl
}

Streszczenie: W kształtowaniu przestrzeni zazwyczaj przyjmowane są standardy wynikające z przyjętych powszechnie rozwiązań mających zaspokajać ludzkie potrzeby. Niestety często środki okazują się ważniejsze niż cele. Dążąc do zapewnienia mobilności i jednocześnie ochrony przed uciążliwościami transportu ogromne przestrzenie przeznacza się na wyalienowane z otoczenia trasy komunikacyjne i przestrzenie izolujące. Są jednak inne rozwiązania. Spektakularnym przykładem jest Wenecja - miasto, którego spora część jest niedostępna dla samochodów. Zatem pozbawiona jest związanych z ich obecnością uciążliwości, ale także możliwości wykorzystania ich w wielu różnych celach. W Wenecji w rolach w większości świata zarezerwowanych dla samochodów występują różnego rodzaju łodzie i statki. Warto zwrócić uwagę na szereg codziennych sytuacji z funkcjonowania części Wenecji pozbawionej samochodów. Zastępuje je nie tylko transport wodny, ale także pieszy. Znaczenie dla codzienności Wenecji ma także kameralna skala pieszych placów i uliczek. Wenecja boryka się z problemem utraty mieszkańców wypieranych przez turystów, oraz wypierania funkcji służących mieszkańcom przez przeznaczone dla turystów. Jednakże te problemy nie powinny dyskredytować organizacji przestrzeni w mieście. Są one bowiem skutkiem ubocznym sukcesu turystycznego wynikającego z wyjątkowej jakości miejsca. Przykłady rozwiązań opartych na odrzuceniu podporządkowania przestrzeni samochodom można znaleźć także w wielu innych miejscowościach, na terenie których odrzucenie dominacji samochodu nie przybrało takiej skali jak w Wenecji. Przykłady można znaleźć także w Polsce. Inne relacje przestrzenne powodują inne relacje między różnymi użytkownikami, a także inne relacje między przebywaniem w mieście, a przemieszczaniem się przez nie.

Słowa kluczowe: Wenecja, funkcjonowanie miasta, ruch pieszy, transport w mieście, transport wodny, przestrzeń miasta, przebywanie w mieście.

\section{Wprowadzenie}

Modernistyczna organizacja przestrzeni z podziałem na strefy o ściśle określonych funkcjach, obszernymi terenami otwartymi i dominacją ruchu samochodowego od dziesięcioleci wywołuje krytyczne refleksje. Spośród wydanych w języku polskim książek reprezentujących ten kierunek myślenia najbardziej klasyczną jest Śmierć $i$ życie wielkich miast Ameryki autorstwa Jane Jacobs [1]. W ostatnich latach popularność w świecie zdobywa duński architekt Jan Gehl, realizujący projekty poprawy funkcjonowania różnych miast. Jest on także autorem publikacji na ten temat, w których szczegółowo analizuje sposób funkcjonowania różnych przestrzeni miejskich. W języku polskim wydano dwie z nich Życie 
między budynkami. Użytkowanie przestrzeni publicznych [2] i Miasta dla ludzi [3]. W obu książkach, przywoływany jest przykład Wenecji, o której Gehl pisze, iż „(...) jest szczególnie interesująca jako model projektowania w ludzkim wymiarze (...)" [3]. Podążając śladem Jana Gehla, chcę zwrócić uwagę na aspekty funkcjonowania przestrzeni Wenecji, związane z faktem, iż znaczna cześć tego miasta jest niedostępna dla ruchu samochodowego, lecz jest obsługiwana przez poruszające się systemem kanałów łodzie i statki, a także poprzez ruch pieszy i poruszane przez pieszych wózki. Jan Gehl podaje Wenecję jako modelowy przykład zastosowania jednej z czterech wyróżnionych przez niego zasad projektowania ruchu w mieście, którą scharakteryzował w następujący sposób: „Miasto piesze. Przejście od ruchu szybkiego do powolnego na obrzeżach miasta lub danego obszaru. Prosty i nieskomplikowany system ruchu o znacznie wyższym stopniu i większym poczuciu bezpieczeństwa niż w jakimkolwiek innym systemie" [2,3]. Chcę tu przede wszystkim zwrócić uwagę na sposoby radzenia sobie w przestrzeni Wenecji z konsekwencjami przyjętego systemu organizacji ruchu i przestrzeni dla rożnych, mniej dostrzegalnych aspektów jego funkcjonowania, które jednakże bardzo często powodują, iż próby urządzenia miasta $\mathrm{W}$ sposób przyjazny dla pieszych i zachęcający do przebywania w nim są torpedowane przez specjalistów mających na uwadze kwestie techniczno-funkcjonalne. W dalszej części artykułu wspomnę o rozwiązaniach sprzyjających przebywaniu w mieście, zastosowanych w miastach, w których, inaczej niż w Wenecji ruch samochodowy jest obecny na dużej części ich obszaru.

\section{Wenecja - wybrane aspekty funkcjonowania miasta bez samo- chodów}

Dominujący w większości miast świata ruch samochodowy w Wenecji funkcjonuje na powszechnych w świecie zasadach we włączonych do niej administracyjnie miejscowościach położonych na lądzie, oraz na mierzei Lido i niektórych wyspach. Należące administracyjnie do Wenecji wyspy Murano, Burano, Mazzorbo, Giudecca, Torcello i szereg mniejszych wysp, są całkowicie niedostępne dla samochodów. Natomiast stanowiąca zasadniczą część Wenecji, rozcięta licznymi kanałami wielka wyspa, którą można także uznać za zespół wielu niewielkich wysp oddzielonych od siebie kanałami, jest częściowo dostępna dla samochodów. W jej zachodniej części znajduje się parking dla przyjezdnych i plac (Piazzale Roma) z dworcem autobusowym (Fot.1,2). Urządzenie Piazzale Roma wraz z wybudowaniem wielopoziomowego parkingu o 1700 miejsc postojowych było konsekwencją oddania do użytku w 1933 roku czterokilometrowej długości mostu Wolności (Ponte della Libertà). Autorem zarówno mostu jak i założenia Piazzale Roma z parkingiem wielopoziomowym (do lat pięćdziesiątych XX wieku największym w Europie) był inżynier Eugenio Miozzi - od 1931 roku odpowiedzialny za planowanie rozwoju Wenecji. Wraz z założeniem Piazzale Roma i parkingu wybudowano nowy kanał (Rio Nuovo) zapewniający połączenie wodne z placem Św. Marka krótsze o dwa kilometry niż trasa biegnąca przez całą długość największego weneckiego kanału (Canal Grande) [4]. W rejonie Piazzale Roma samochody pełnią także rolę dostawczą i obsługującą. Dodatkowy, ogromny parking został zlokalizowany na wybudowanej w latach 1958-1962, także pod kierunkiem inżyniera Eugenio Miozziego w sąsiedztwie tej części Wenecji sztucznej wyspie Tronchetto. Później wyspę powiększono i wzniesiono na niej parkingi wielopoziomowe [5]. Większość obszaru zasadniczej części Wenecji pozostaje wyłączona z ruchu samochodowego. Do jej zachodniej części od 1861 roku 
dociera także kolej. Obecny budynek dworca (architekt Paolo Perilli) oddano do użytku w 1952 roku [4]. Przewożenie ludzi i towarów odbywa się na terenie Wenecji drogą wodną. Przebywającym na terenie Wenecji od razu rzucają się w oczy statki - tramwaje wodne (Fot. 2, 13, 14), noszące nazwę vaporetto, wywodzącą się z czasów, kiedy były to statki parowe. Jednakże przy bacznej obserwacji można dostrzec także łodzie i statki służące wielu innym różnym celom, którym w większości świata służą pojazdy samochodowe. Są więc statki i łodzie policji, straży pożarnej (Fot. 5, 6), pogotowia ratunkowego (Fot. 9, 10), czy kontroli skarbowej. Z łodzi sprzedawane są warzywa (Fot. 11). Łodziami odbywa się transport zmarłych w trumnach (Fot. 3), materiałów budowlanych i gruzu (Fot. 8, 25), a także szeregu innych przedmiotów i towarów (Fot. 4, 7, 12).

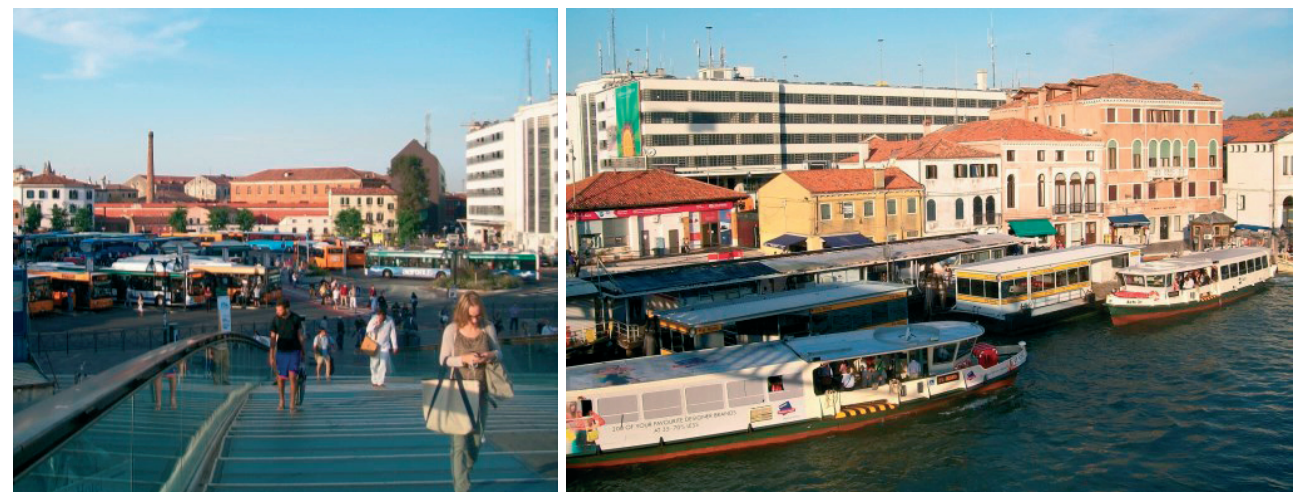

Fot. 1,2. Wenecja. Piazzale Roma - miejsce przesiadek z komunikacji drogowej na wodną. Na zdjęciu z lewej widoczny fragment dworca autobusowego, na zdjęciu z prawej przystań miejskiej komunikacji wodnej. Widoczny na obu zdjęciach modernistyczny budynek z pasami białej elewacji i pasami przeszkleń to wielopoziomowy garaż dla samochodów osobowych. Zdjęcia: Hubert Trammer, 29 sierpnia 2012 roku
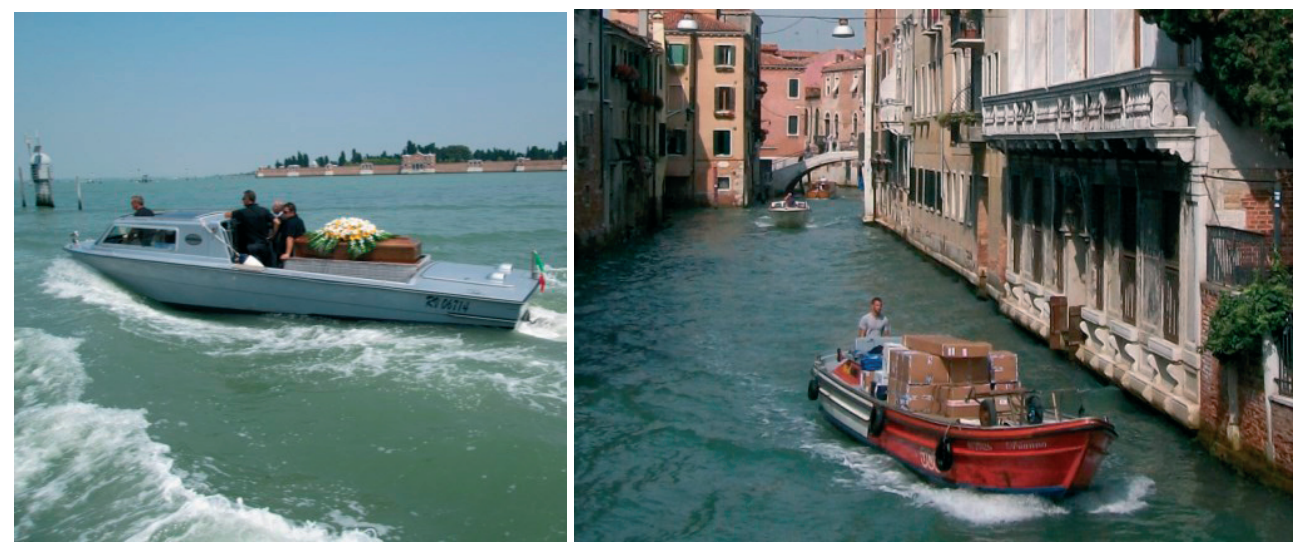

Fot. 3,4. Przykłady wykorzystania w Wenecji łodzi w rolach najczęściej spełnianych przez samochody. $\mathrm{Z}$ lewej: łódź-karawan $\mathrm{z}$ trumną na lagunie na północ od Wenecji. W głębi widoczna, zajęta $\mathrm{W}$ całości przez cmentarz, wyspa San Michele (7 czerwca 2014 roku). Z prawej: przewóz paczek łodzią (27 sierpnia 2010 roku). Zdjęcia: Hubert Trammer 

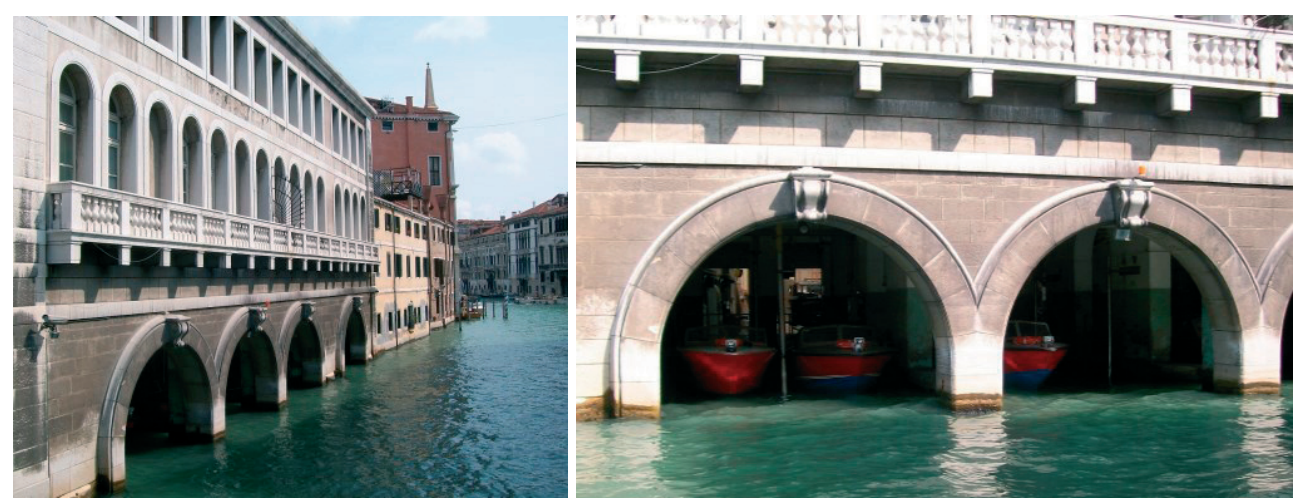

Fot. 5,6. Remiza strażacka przy kanale Rio di Ca' Foscari w Wenecji. Na zdjęciu z prawej widoczne łodzie strażackie. Zdjęcia: Hubert Trammer, 27 sierpnia 2010 roku
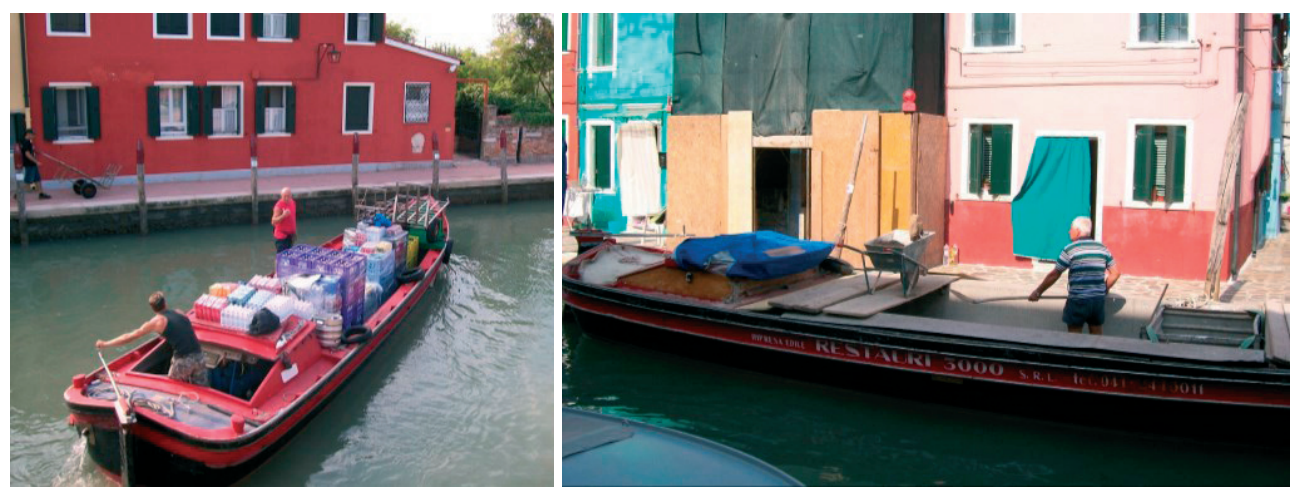

Fot.7,8. Przykłady wykorzystania łodzi w rolach najczęściej spełnianych przez samochody. Z lewej: łódź dostarczającą towar do sklepów spożywczych i lokali gastronomicznych (kanał na wyspie Torcello). Z prawej: wyładunek piasku z łodzi na taczkę (kanał na wyspie Burano). Zdjęcia: Hubert Trammer. 25 sierpnia 2010 roku
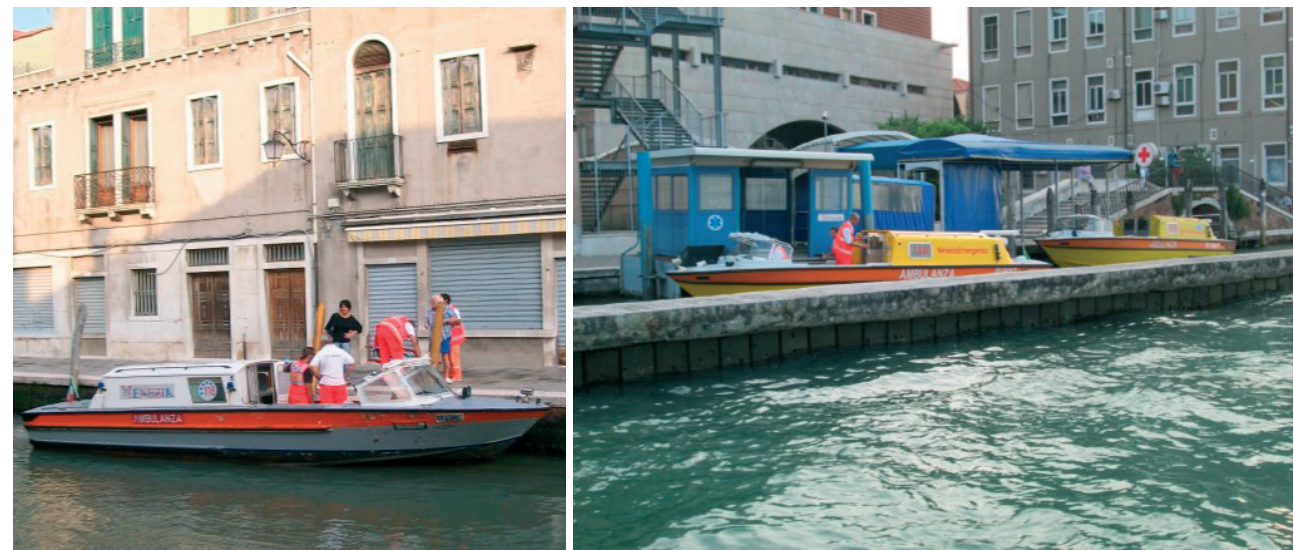

Fot. 9,10. Wodne karetki pogotowia. Z lewej: przyjazd po chorego (Murano, 25 sierpnia 2010 roku). Z prawej: miejsce przywozu chorych na izbę przyjęć szpitala (Wenecja, 6 czerwca 2014 roku). Zdjęcia: Hubert Trammer 

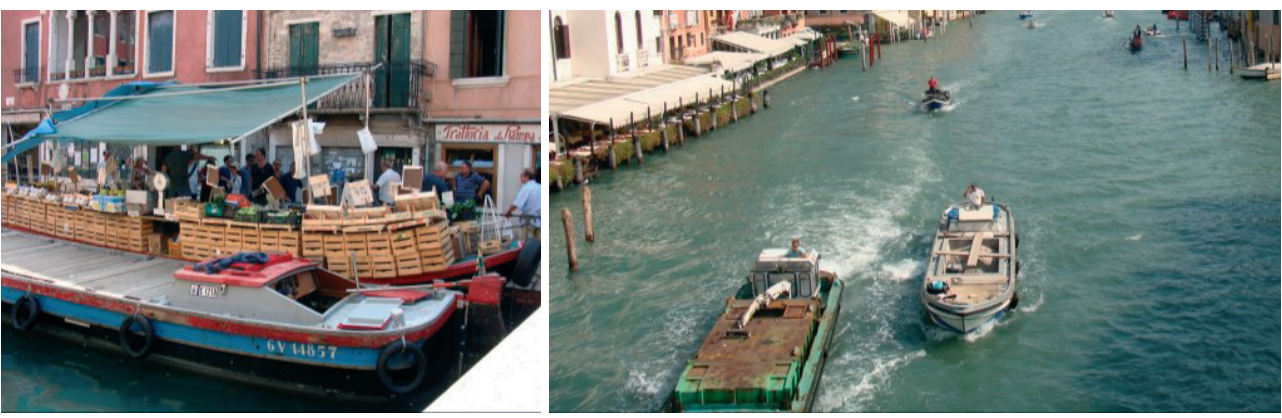

Fot. 11,12. Łodzie w życiu Wenecji. Z lewej: sprzedaż warzyw z łodzi przy Fondamente di Santa Anna. Z prawej: statek śmieciarka i statek ciężarówka na Canale Grande. Zdjęcia: Hubert Trammer. 12 września 2008 roku
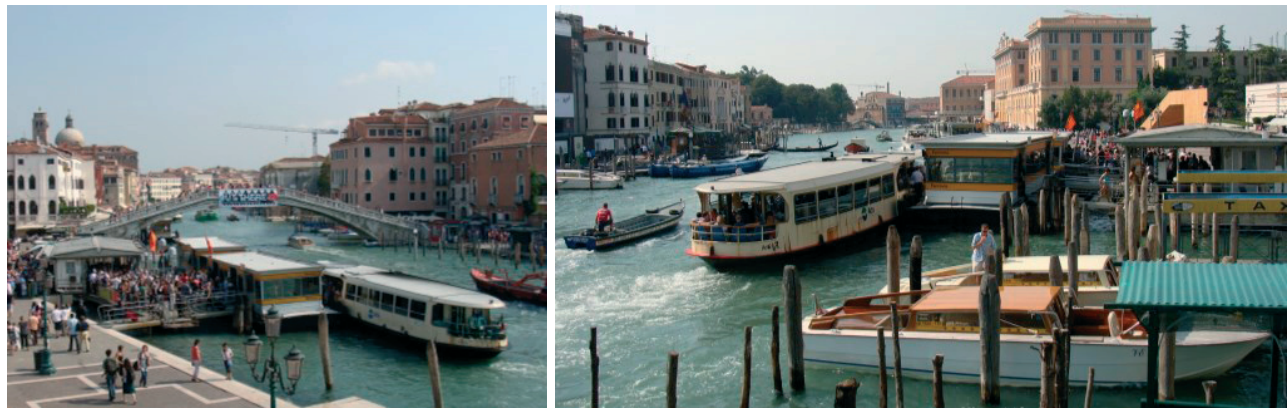

Fot. 13,14. Canale Grande w rejonie dworca kolejowego Venezia Santa Lucia. Na obu zdjęciach widoczne przystanki tramwaju wodnego i sam tramwaj wodny (Vaporetto). Zdjęcia: Hubert Trammer. 12 września 2008 roku

Samochody mogą w prosty sposób dokonywać ekspansji na chodniki, dziedzińce, czy inne przestrzenie poza drogami. Czasem oznacza to dewastacje przez samochody trawników. Łodzie mogą być wyjmowane na brzeg, ale wymaga to szczególnego wysiłku, zaś po lądzie poruszać się mogą specjalne statki, czy łodzie amfibie, bądź też statki korzystające ze specjalnych instalacji - jak te zastosowane na Kanale Elbląskim. W Wenecji widok łodzi znajdującej się na lądzie jest niezmiernie rzadki. Ogranicza się niemal wyłącznie do warsztatów szkutniczych. Wynika to prawdopodobnie z tego, iż stosowane w Wenecji łodzie są w większości ciężkie, a także z ograniczonej ilości miejsca w gęsto zabudowanym mieście. Jednak pomimo ograniczonej ilości miejsca w przestrzeni Wenecji można spotkać obszerne bulwary nabrzeżne, czy też spore place, które gdyby znajdowały się w miastach, w których podstawowym środkiem lokomocji jest samochód z pewnością w pewnym okresie historii zostałyby zaanektowane przez samochody. W Wenecji pozostały domeną ruchu pieszego i przebywania w nich ludzi (Fot. 15, 16).

Nie dotarłem do informacji dotyczących powodów wprowadzenia organizacji ruchu wykluczającej z większości obszaru Wenecji ruch samochodowy. Można przypuszczać, iż wynikała ona z faktu, iż obszerne place i szerokie ulice, czy nadbrzeża są w Wenecji miejscami szczególnymi. Większość miasta wypełnia gęsta zabudowa rozmieszczona pośród sieci wąskich uliczek i niewielkich placyków. Umożliwienie ruchu samochodowego na całym obszarze Wenecji wymagałoby zmiany struktury miasta pociągającej za sobą daleko idące wyburzenia. Jednocześnie sieć kanałów zapewnia dostęp transportu wodnego do całego obszaru miasta. Jednakże nie jest ona na tyle gęsta, aby zapewnić dostęp do każdej 
posesji. Dlatego transport wodny musi mieć swoje uzupełnienie. Stanowią je wózki pchane przez ludzi. Śmieci są wystawiane przez mieszkańców na ulice w workach. Śmieciarze zbierają je do specjalnych wózków, którymi dowożą worki ze śmieciami do łodziśmieciarek (Fot. 12, 17-20). Wózki służą także do transportu sprzętu i towarów z łodzi do domów i sklepów. Często sprzęt i urządzenia nie są przewożone indywidualnie łodzią, lecz wraz wózkiem płyną na pokładzie tramwaju wodnego. Sprzyja temu pozbawiony schodów dostęp na pokład, a także rozmiary tramwajów wodnych - obszerniejsze niż autobusów czy tramwajów kursujących w miastach opartych na ruchu samochodowym (Fot. 21-24, 26).
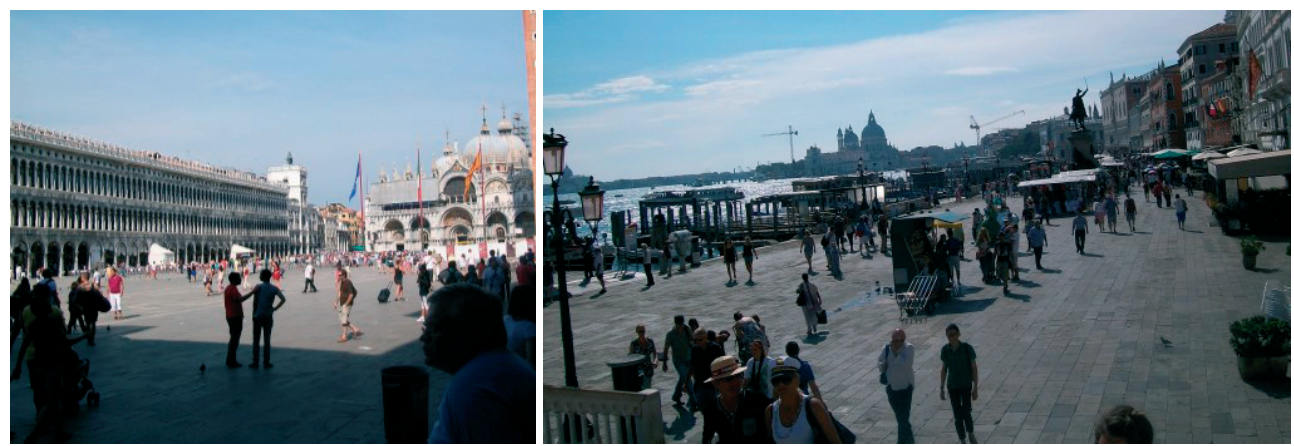

Fot. 15,16. Wenecja. Z lewej: Plac Świętego Marka. Z prawej: Riva degli Schiavoni - obszerny bulwar nadbrzeżny. Obszerne przestrzenie dla ruchu pieszego i przebywania w nich. Zdjęcia: Hubert Trammer. 26 sierpnia 2012 roku
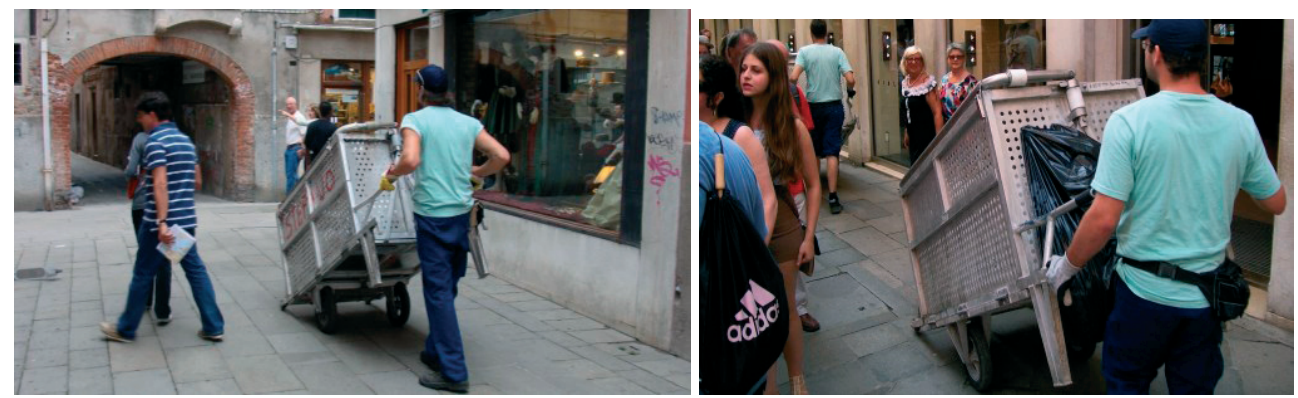

Fot. 17,18. Weneccy śmieciarze z wózkami do transportu śmieci z miejsc ich wystawiania do statkówśmieciarek. Zdjęcia: Hubert Trammer. 13 września 2008 roku ( z lewej) i 26 sierpnia 2012 ro$\mathrm{ku}$ (z prawej)
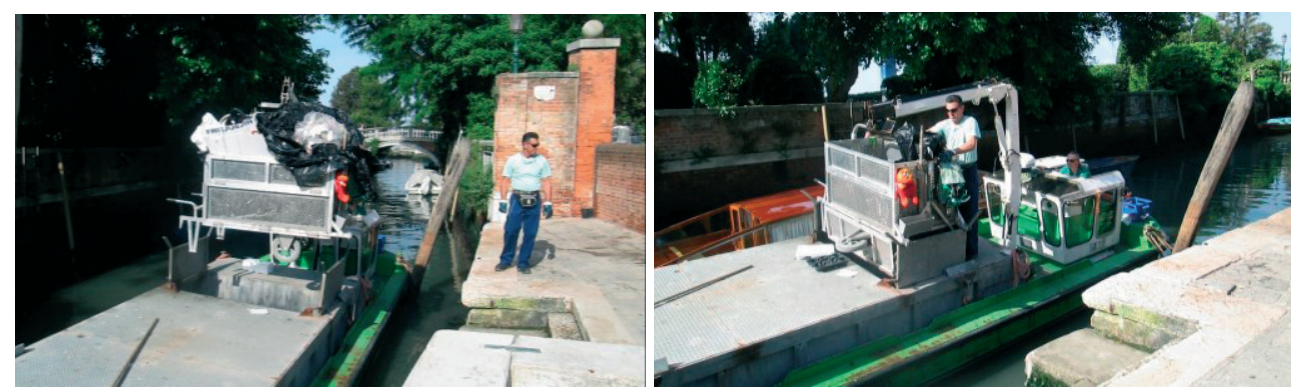

Fot. 19,20. Wenecja. Przeładunek śmieci z wózków na statek- śmieciarkę. Zdjęcia: Hubert Trammer, 25 maja 2016 roku. 

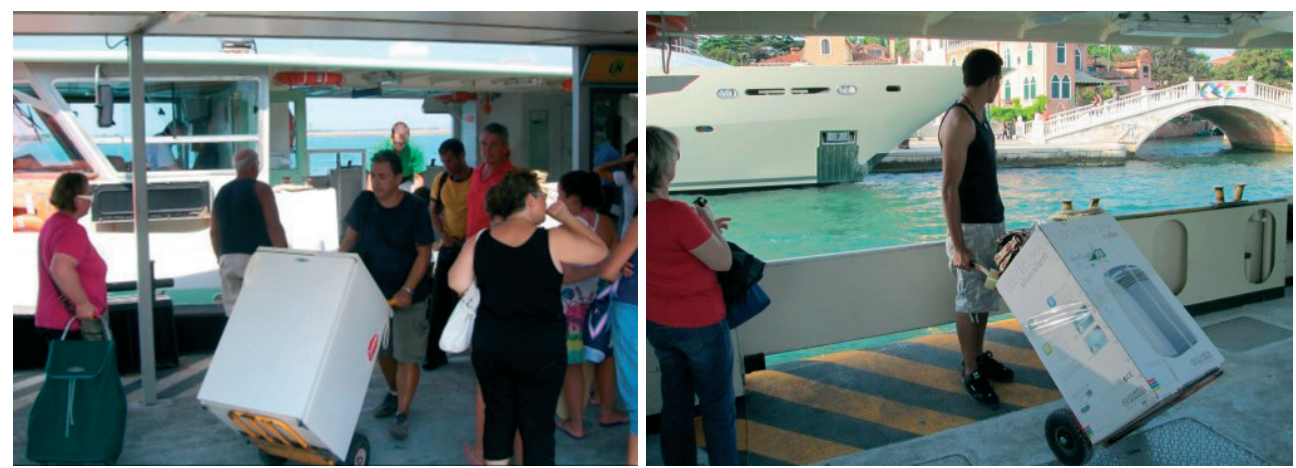

Fot. 21,22. Transport sprzętu domowego na wózkach przewożonych weneckimi tramwajami wodnymi. Z lewej przewóz lodówki ( 25 sierpnia 2010 roku), z prawej klimatyzatora (7 czerwca 2014 roku). Zdjęcia: Hubert Trammer
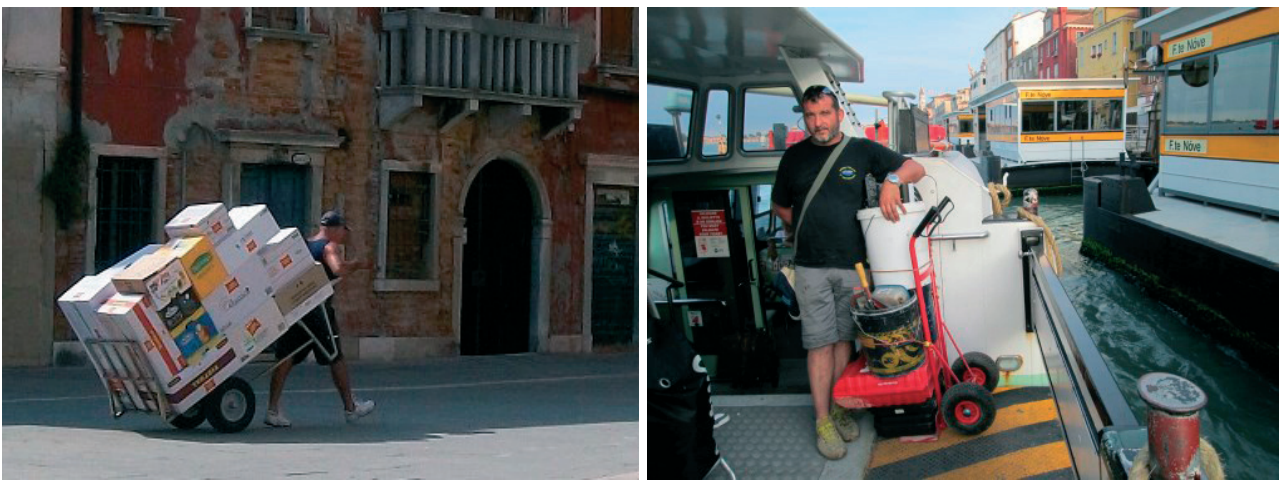

Fot. 23,24. Wenecja. Z lewej: Transport paczek wózkiem (27 sierpnia 2010 roku). Z prawej: transport sprzętu do prac remontowych na wózku przewożonym tramwajem wodnym (6 czerwca 2014 roku). Zdjęcia: Hubert Trammer
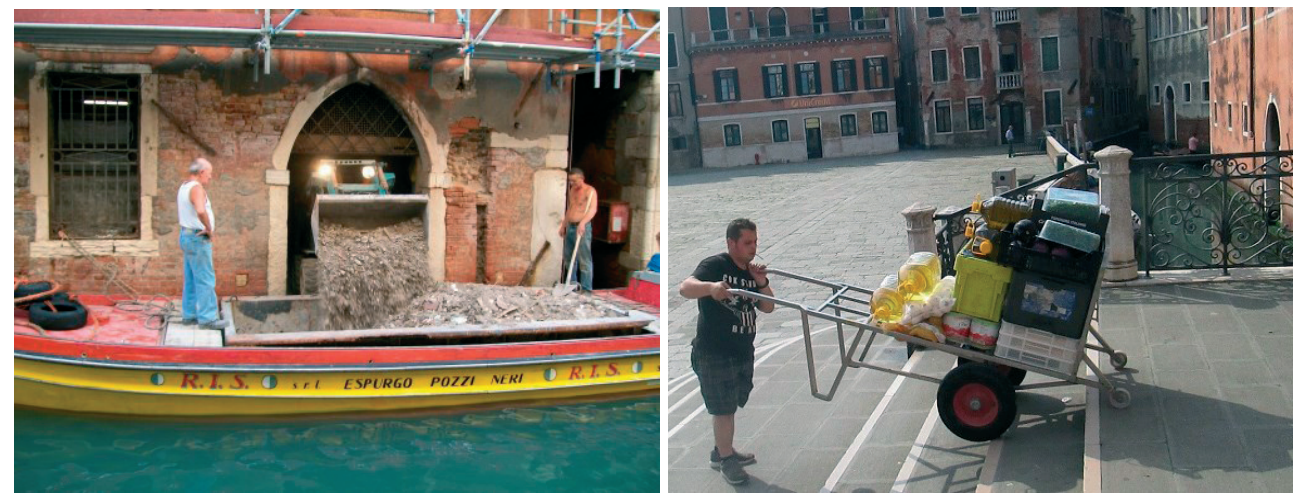

Fot. 25,26. Wenecja. Z lewej: Wyładunek gruzu przez ładowarkę poruszającą się wewnątrz budynku do łodzi - ciężarówki (26 sierpnia 2010 roku). Z prawej: Transport artykułów spożywczych wózkiem z kółkami ułatwiającymi pokonywanie schodów (27 maja 2016 roku). Zdjęcia: Hubert Trammer 

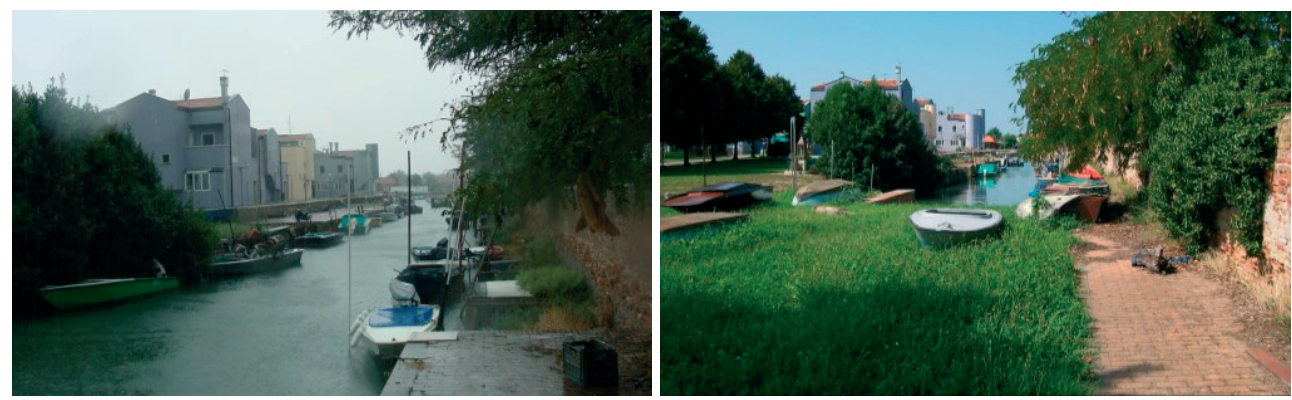

Fot. 27,28. Wyspa Mazorbo. Kanał odgrywający rolę parkingu dla łodzi przy osiedlu mieszkaniowym. Zdjęcia: Hubert Trammer. Z lewej: 13 września 2008 roku, z prawej 25 sierpnia 2010 roku
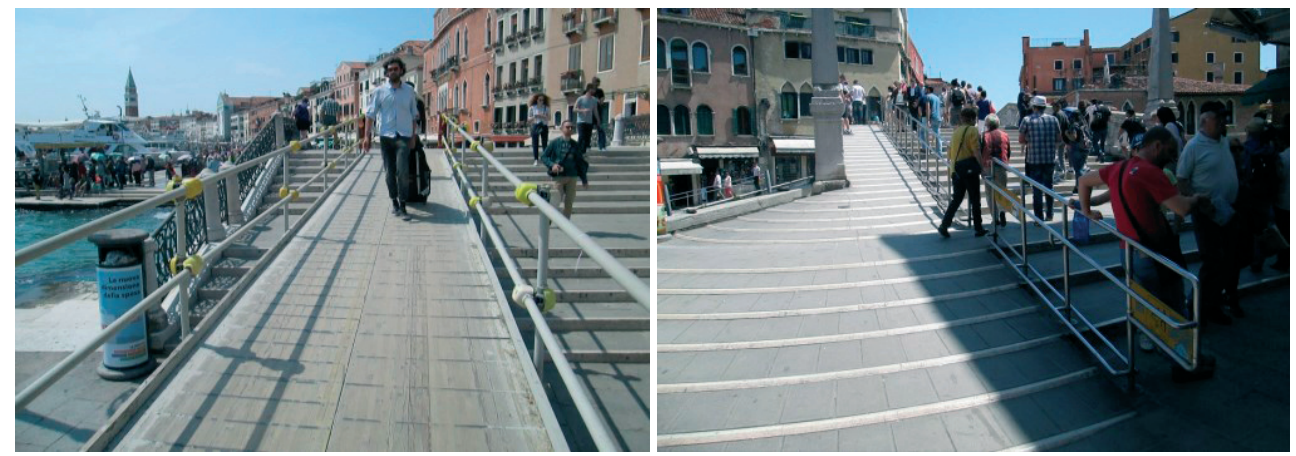

Fot. 29,30. Wenecja. Dostosowanie mostów pieszych do transportu na wózkach. Z lewej: rozwiązanie prowizoryczne, ale funkcjonujące od kilku lat i sprawdzające się pod względem użytkowym most nad Rio Ca' di Dio na końcu Riva degli Schiavoni. Z prawej: most dostosowany do ruchu wózków w sposób trwały i nawiązujący do jego zabytkowej formy - Ponte delle Guglie nad Canale di Canareggio. Zdjęcia Hubert Trammer (25 i 28 maja 2016 roku)
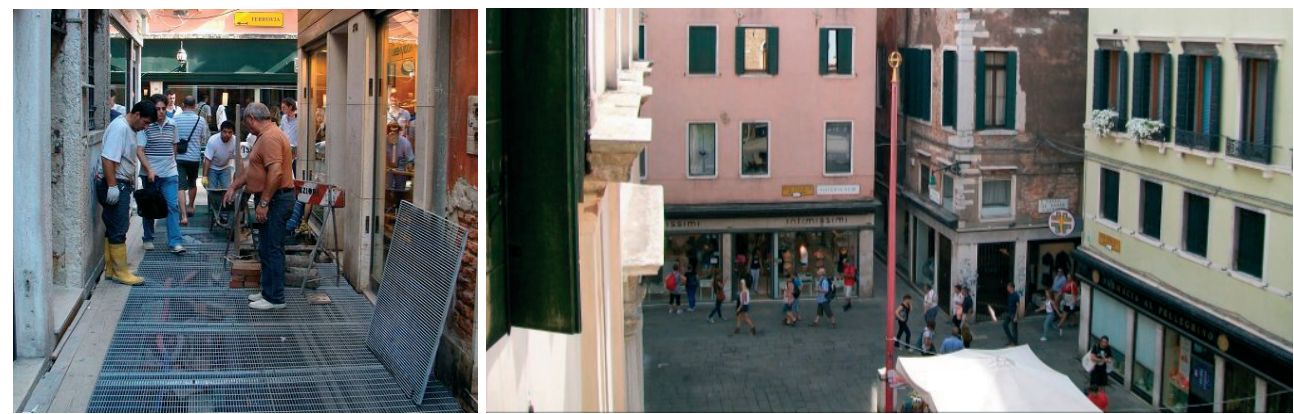

Fot. 31,32. Funkcjonowanie kameralnych przestrzeni uliczek i placów pieszych Wenecji. Z lewej: tymczasowa nawierzchnia z krat pomostowych umożliwiająca ruch pieszych podczas trwających pod spodem prac przy instalacjach podziemnych (12 września 2008 roku). Z prawej: Widok z góry na Campo San Lio (26 sierpnia 2012 roku) Zdjęcia: Hubert Trammer

Będący kręgosłupem głównej części Wenecji Canale Grande ma przebieg w kształcie litery S. Duża część kanałów jest zbyt wąska dla ruchu tramwajów wodnych. Dlatego zawsze pomiędzy wieloma, nawet dość oddalonymi od siebie, punktami dojście piesze 
zajmowało mniej czasu niż podróż z użyciem tramwaju wodnego. To sprzyja wzrostowi znaczenia komunikacji pieszej. Tym bardziej, że najdalej od siebie położone punkty głównej weneckiej wyspy dzieli w linii prostej niespełna pięć kilometrów. Konkurencyjności ruchu pieszego dodatkowo sprzyja to, iż z najwęższych kanałów, którymi przebiegały linie tramwajów wodnych ich ruch został wycofany. Przestały kursować między inny przez Rio Nuovo - wspomniany wcześniej, wytyczony w latach trzydziestych XX wieku nowy kanał skracający o dwa kilometry drogę wodną z Piazzale Roma do Piazza San Marco. Obecnie ruch tramwajów wodnych odbywa się między wyspami, wokół głównej weneckiej wyspy, zaś wewnątrz niej jedynie przez Canale Grande i Canale di Canareggio. To oznacza, że trasy wielu linii tramwajów wodnych zostały dodatkowo wydłużone względem wcześniejszych ich przebiegów, a także względem tras dojść pieszych. Czas podróży tramwajem wodnym wydłuża ponadto konieczność cumowania i odcumowywania na każdym przystanku. Opłaty za przejazd są wysokie. Jednocześnie atrakcyjny charakter przestrzeni Wenecji sprawia, iż poruszanie się po niej pieszo jest przyjemne. Z pewnością znaczenie ma brak samochodów i wypuszczanych przez nie spalin. Pewną uciążliwością jest konieczność pokonywania schodów przy wejściach na większość mostów i mostków nad kanałami. Stopniowo jednak coraz więcej z nich jest dostosowywane do ruchu wózków inwalidzkich, wózków z dziećmi i wózków do przewożenia towarów. W niektórych przypadkach ma to charakter dość prowizoryczny i wątpliwą jakoś estetyczną. W innych zastosowano rozwiązania wysokiej jakości. Obie sytuacje oznaczają poprawę warunków transportu z wykorzystaniem wózków (Fot. 29,30).

\section{Funkcjonowanie Wenecji jako miasta bez samochodów a ogólna sytuacja miasta}

Stara część Wenecji traci mieszkańców. W roku 1960 było ich ponad 100 tysięcy, zaś w roku 2008 poniżej 60 tysięcy [4]. Ten fakt łatwo uznać za argument na rzecz tezy, iż sposób organizacji przestrzeni i transportu w Wenecji nie sprawdza się, a mieszkańcy uciekają na stały ląd w poszukiwaniu niedostępnych na jej obszarze udogodnień, w tym takich, jakie daje samochód. Koszty transportu w Wenecji są wysokie. Pociąga to za sobą wzrost szeregu innych kosztów. Wysokie są też koszty zamieszkiwania. Nie da się ukryć, iż transport powolnymi łodziami i wózkami poruszanymi przez ludzi jest w realiach krajów wysokorozwiniętych kosztowniejszy niż masowy transport samochodowy. Po części jednak wynika to $z$ faktu, iż dominująca rola transportu samochodowego w świecie sprawiła, iż dostosowano do niego szereg rozwiązań i urządzeń. Jednocześnie trzeba pamiętać, iż Wenecja jest miastem szczególnym nie tylko pod względem organizacji przestrzeni i transportu. Jej gospodarka zdominowana jest przez turystykę. Ceny zamieszkiwania i usług w Wenecji podnosi także to, iż od przybywających na krótko turystów można za określoną usługę czy określony czas zamieszkiwania uzyskać dużo wyższe kwoty niż od stałych mieszkańców. Wiele osób pracujących w Wenecji przy obsłudze turystów czy w innych usługach nie może sobie pozwolić na mieszkanie na jej terenie. Co więcej same tłumy turystów dla niektórych stanowią czynnik zniechęcający do mieszkania w starej części miasta. Na weneckiej wyspie cały czas funkcjonują wyższe uczelnie, urzędy o randze regionalnej i inne ważne instytucje. Opuścił je w dużej części przemysł. Teren po nim częściowo zajęły hotele, a częściowo socjalne osiedla mieszkaniowe, które wybudowano po to aby poprzez stworzenie tanich mieszkań zatrzymać utratę przez miasto mieszkańców [4].

Problem wyludniania się Wenecji należy więc uznać w dużym stopniu za konsekwencję jej atrakcyjności turystycznej. Wenecja jest bardzo bogata w zabytki. Zarówno zabyt- 
kowe budynki, przestrzenie miejskie, jak i w zabytkowe dzieła sztuki. Odbywa się w niej szereg wydarzeń kulturalnych i naukowych. Stąd też trudno jednoznacznie określić na ile ściąga do niej przybyszów fakt, iż jest to miasto na wodzie ze szczególną organizacją transportu i przestrzeni. Przy tym sama organizacja transportu i przestrzeni, oraz wynikający z niej urok miasta są odkrywane dopiero na miejscu. Mają więc raczej znaczenie dla decyzji o przedłużeniu pobytu lub o kolejnych wizytach. Natomiast sława miasta na wodzie jest szeroka i przyciąga mieszkańców. Notabene bardzo wiele innych miast świata, w których przestrzeni woda odgrywa istotne znaczenie jest porównywanych do Wenecji.

Podjęcie działań zmierzających do dostosowania Wenecji do poruszania się po całym jej terenie samochodami wymagałoby wyburzenia wielu cennych zabytków i poniesienia niewyobrażalnych kosztów ekonomicznych. Z pewnością zmniejszyłoby atrakcyjność turystyczną miasta, ale raczej nie odwróciłoby niekorzystnego trendu utraty mieszkańców. Nie można zapominać, iż jednoznacznie negatywne zjawisko utraty mieszkańców nie oznacza iż z Wenecji korzysta mniej ludzi. Można znaleźć źródła mówiące o ponad 20 milionach turystów przybywających rocznie do Wenecji i 40 tysiącach osób przybywających codziennie do miejsca pracy lub nauki w Wenecji z poza jej terenu [6]. W gminie Wenecja w latach pięćdziesiątych XX wieku rocznie zatrzymywało się na pobyt kilkaset tysięcy turystów, w roku 2002 było to 2.721 .656 , zaś w roku 20144.280 .632 , z czego do samej historycznej części 2.599.126 [7]. Pełnomorskimi statkami wycieczkowymi przybyło do położonego w starej części Wenecji portu w 1996 roku około 260 tysięcy ludzi, zaś w roku 2010 około dwóch milionów. Ma to związek z przeniesieniem z Wenecji na stały ląd portu towarowego [4]. Jest to więc kolejny aspekt przemiany gospodarki Wenecji w kierunku monokultury turystycznej. Notabene wielkie turystyczne statki wycieczkowe, a ściślej wywoływane przez nie fale są postrzegane jako zagrożenie dla budowli Wenecji.

Można więc uznać, iż problem nie leży w braku atrakcyjności Wenecji, ale w tym że jej ogromna atrakcyjność turystyczna powoduje presję cenową prowadzącą do wyparcia mieszkańców. Zatem problemem jest relacja turystyki do innych aspektów funkcjonowania miasta. Sama zaś organizacja przestrzeni i transportu ma tylko znaczenie jako element zwiększający atrakcyjność miasta. Można też postawić tezę, iż zarazem ogranicza ona skalę problemów wynikających z liczby turystów. Bowiem ludzie poruszający się pieszo stanowią mniejsze obciążenie dla miasta i środowiska niż gdyby poruszali się samochodami czy autokarami.

\section{Organizacja przestrzeni miejskiej z samochodami w pozycji podporządkowanej}

Wacław Ostrowski w książce Wprowadzenie do historii budowy miast. Ludzie i środowisko stwierdził: „(...) olśnienie miał Le Corbusier w Wenecji: oto raj dla pieszych! Szkicuje krajobraz wenecki z siecią ulic i mostów przerzuconych nad kanałami - i wprowadza dwupoziomowy system ulic pieszych i dróg kołowych do swych projektów urbanistycznych. W opisie „Miasta Promiennego” brzmią echa Wenecji: „Od autostrad rozchodzą się odgałęzienia prowadzące do portów samochodowych przed wejściami do budynków". (...)" [8]. Faktycznie, intuicyjnie może się wydawać, iż system ulic samochodowych, nad którymi piesi przechodzą mostkami da efekt bliski Wenecji. Jednakże doświadczenie z funkcjonowania takich systemów pokazuje, iż samochody poruszające się dużo szybciej niż statki i łodzie w Wenecji, a przez to produkujące więcej hałasu i spalin niż statki w Wenecji, powodują, iż porównanie $\mathrm{z}$ weneckimi kanałami jest całkowicie chybione. Sąsiedztwo takich ulic do wyłącznego ruchu samochodów w niczym nie przypomina nabrzeży nawet ruchliwych weneckich kanałów. 
Dość dobre efekty daje wprowadzona w wielu osiedlach segregacja ruchu pieszego i samochodowego wprowadzona w podobny sposób jak w Wenecji, ale bez zastępowania łodzi i statków samochodami, a z zastosowaniem weneckiej zasady pozostawiania samochodów poza osiedlem. Jednakże nie zawsze udaje się utrzymać konsekwencję w niedopuszczaniu samochodów do wnętrza osiedla. Różnica względem Wenecji objawia się zwykle także w tym, iż wiele z takich osiedli ma dużo mniejszą niż Wenecja gęstość zabudowy i dużo większą skalę przestrzeni. Jednakże w tych w nich gdzie zabudowa jest gęstsza, czy też na terenie wielu górskich miasteczek można dostrzec pokrewieństwo z Wenecją. Nawet gdy nie ma kanałów. Zresztą Jan Gehl także przywołuje wenecką organizację ruchu jako model stosowany w różnych miastach i osiedlach $[2,3]$.

Paradoksalnie warunki funkcjonowania pieszych i charakter przestrzeni miejskich dużo bardziej zbliżony do weneckiego, niż w przypadku krzyżujących się w różnych poziomach układów ulic pieszych i samochodowych, dają rozwiązania gdzie ruch pieszy jest zintegrowany z ruchem samochodów lub innych pojazdów, ale organizacja przestrzeni jest podporządkowana ruchowi pieszemu. Jan Gehl w swoim zestawieniu czterech zasad projektowania komunikacji jako przykład podaje tu holenderskie miasto Delft [2, 3] i opisuje je w następujący sposób: „Integracja ruchu odbywa się na zasadach wyznaczonych przez powolny ruch. Rozwiązanie wprowadzono w Delft w 1969 roku. Jest to prosty, klarowny i bezpieczny system traktujący ulice jako najważniejsze przestrzenie publiczne. W miejscach, w których samochody muszą dojechać do budynków, integracja ruchu z pierwszeństwem ruchu pieszych jest najlepszym rozwiązaniem” [3]. Jak stwierdza Gehl „(...) Gdy ruch uliczny składa się z pieszych lub samochodów poruszających się z małą prędkością, argumenty za separacją stref przebywania i zabawy od stref ruchu tracą swą ważność. (...)" [2]. Organizacja przestrzeni oparta na wzorach holenderskich i nazywana holenderskim słowem woonerf z powodzeniem wprowadzana jest na kolejnych ulicach Łodzi od 2014 roku, kiedy to w woonerf przekształcono ulicę 6 sierpnia (fot. 33 i 34). Co ciekawe sprawdza się ono na ulicach położonych w centrum miasta i obciążonych dość sporym ruchem tranzytowym. Pojawiło się ono w Łodzi za sprawą zgłoszenia go w ramach procedury budżetu partycypacyjnego. W ciągu pierwszych dwóch lat funkcjonowania nie zdarzył się tam ani jeden wypadek [9]. Po Łodzi woonerfy wprowadzają kolejne polskie miasta. Różne przykłady rozwiązań przyjaznych pieszym z ruchem samochodowym wkraczającym w domenę ruchu pieszego na zasadzie podporządkowanej zamierzam szerzej zaprezentować w osobnym artykule.
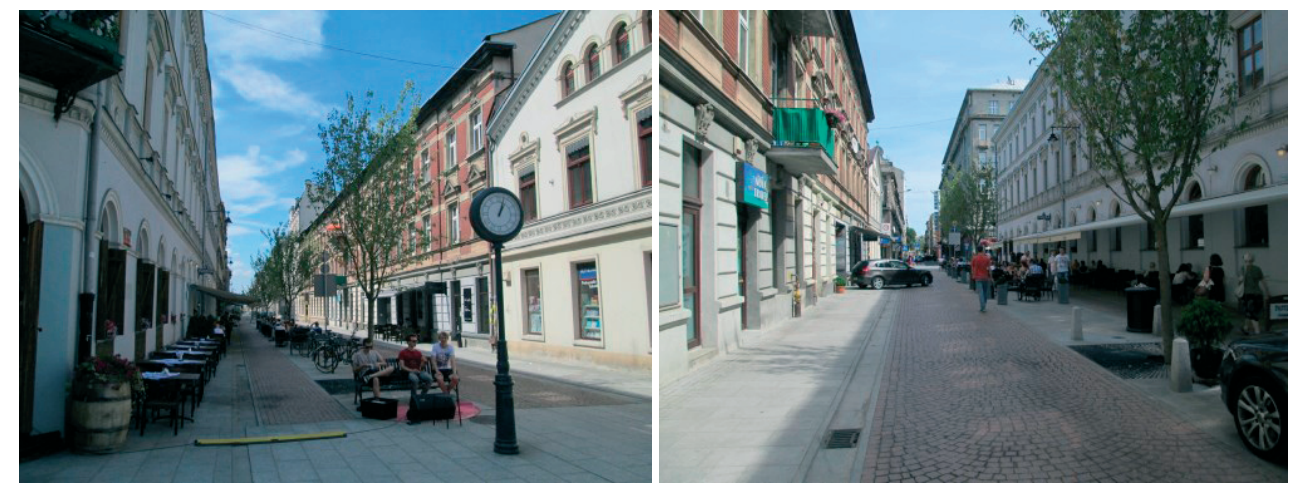

Fot. 33,34. Ulica 6 sierpnia w Łodzi przekształcona w pierwszy w Łodzi woonerf. Zdjęcia: Hubert Trammer (10 sierpnia 2014 roku) 


\title{
5. Podsumowanie
}

Wenecja, miasto głośne w ostatnim czasie za sprawą mieszkańców protestujących przeciwko dominacji turystów i podkreślających problem utraty przez miasto mieszkańców [6], nie wydaje się tak zachęcającym wzorem jak w czasach kiedy Jan Gehl przywoływał ją W swoich książkach [2,3]. Jednakże problemy Wenecji nie oznaczają, iż miasto po prostu upada, lecz to, iż jest ofiarą własnego sukcesu. Być może także z tego, iż nie ma konkurencji innych miast.

Dlatego nie dyskredytuje to Wenecji jako modelu organizacji przestrzeni miejskiej. Jest ona interesującym polem do analiz dotyczących organizacji przestrzeni i życia w mieście w sposób inny od powszechnie dominującego w dzisiejszych czasach.

\section{Literatura}

1. Jacobs J. Śmierć i życie wielkich miast Ameryki, Fundacja Centrum Architektury, Warszawa, 2014.

2. Gehl J. Życie między budynkami. Użytkowanie przestrzeni publicznych, Wydawnictwo RAM, Kraków, 2009.

3. Gehl J. Miasta dla ludzi, Wydawnictwo RAM, Kraków, 2014.

4. Kusch C.F., Gelhaar A. Architectural Guide. Venice. Buildings and Projects After 1950, DOM publishers, Berlin, 2014.

5. https://cs.wikipedia.org/wiki/Tronchetto - dostęp dnia 15 września 2016 roku

6. AFP, Venetians hold rally to fight city's exodus, http://www.thelocal.it/20161113/venetiansrally-to-fight-citys-exodus - dostęp dnia 3 grudnia 2016 roku

7. Miraglia A., Callegaro N., Niero L., Galasso M. Annuario del Turismo 2014, Comune di Venezia CPM Editoria per le comunicazione, Wenecja, 2015.

8. Ostrowski W. Wprowadzenie do historii budowy miast. Ludzie i środowisko, Oficyna Wydawnicza Politechniki Warszawskiej, Warszawa, 1996.

9. Kubecka M., Zimny B. Kierowca syty i pieszy caty, Magazyn Miasta 14 (2016) 133.

\section{Different everyday. Functioning of Venice as a city without cars}

\author{
Hubert Trammer \\ Chair of Architecture Urban Design and Spatial Planning, \\ Faculty of Civil Engineering and Architecture, Lublin University of Technology, \\ e-mail:huberttrammer@wp.pl,h.trammer@pollub.pl
}

\begin{abstract}
Shaping of the space generally follows the standards which are created in search for fulfilling the human needs. Unfortunately the means often became more important than the goals. In order to provide mobility and at the same time protection from the oppressiveness of transportation the huge space is lost for the transportation roads which are alienated from their surrounding and for the buffer spaces. There are different solutions. The spectacular example of their use is Venice - the city big part of which is inaccesibble for cars. It means it is free from oppressiveness connected with the presence of cars, but also it does not use the possibilities given by using cars for different needs. The function
\end{abstract}


reserved in majority of the world for cars in Venice is provided by different kinds of boats. It is worth to pay attention on different everyday situations from the part of Venice which is free of cars. They are substituted not only by water transit but also by the pedestrian transit. The small scale of the streets and squares of Venice also has an important meaning for the everyday of the city. Venice faces a serious problem of the loss of its inhabitants which are pushed out of the city by the tourists. Also the functions which serve the inhabitants are pushed out by the functions for tourists. However the problems of the city should not discredit the management of the traffic in the city. The problems are the site effect of success of Venice as a tourist destination which follows the unique quality of the place. The examples of the solutions which base on the rejection of the domination of the car in the space of the city one can find also in other places, where the rejection of the hegemony of the cars does not have such a total scale as in Venice. Such examples can be found also in Poland. Different space relations cause different relations between different users, as well as different relations between spending time in the city and passing it through.

Keywords: Venice, functioning of the city, pedestrian traffic, transport in the city, water transport, space of the city, spending time in the city. 